Retraction Notice

\title{
RETRACTED: Implementation of reversible jump MCMC algorithm to segment the piecewise Polynomial Regression
}

\author{
Suparman
}

\author{
Ahmad Dahlan University, Jalan Prof. Dr. Soepomo, S.H. Warungboto, Yogyakarta 55164, Indonesia \\ suparmancict@yahoo.co.id \\ * corresponding author
}

ARTICLE INFO

RETRACTED

Article history:

Retraction notice to "Implementation of reversible jump MCMC algorithm to segment the piecewise Polynomial Regression", Vol 2, No 2, pp. 107-114, July 2016

DOI: https://doi.org/10.26555/ijain.v2i2.62

Retracted on August 21, 2017
Following a rigorous, carefully concerns and considered review of the article published in International Journal of Advances in Intelligent Informatics to article entitled "Implementation of reversible jump MCMC algorithm to segment the piecewise Polynomial Regression" Vol 2, No 2, pp. 88-93, July 2016, DOI: https://doi.org/10.26555/ijain.v2i2.62.

This paper has been found to be in violation of the International Journal of Advances in Intelligent Informatics Publication principles and has been retracted.

The article contained redundant material, the editor investigated and found that the paper published in International Journal of Mathematical, Computational, Physical, Electrical and Computer Engineering, Vol. 10, No. 5 (2016), pp. 232-235, URL: http://scholar.waset.org/1999.7/10004307, entitled "Segmentation of Piecewise Polynomial Regression Model by Using Reversible Jump MCMC Algorithm".

The document and its content has been removed from International Journal of Advances in Intelligent Informatics, and reasonable effort should be made to remove all references to this article.

Copyright () 2017 International Journal of Advances in Intelligent Informatics. All rights reserved. 